\title{
Rys historiograficzny dekady gierkowskiej. Przyczynek do problematyki polskiego piśmiennictwa historycznego na temat lat 70 . XX wieku w Polsce
}

Dekada lat 70. w Polsce jest jednym z najsłabiej zbadanych okresów historycznych w dziejach najnowszych. Większość badań polskich historyków koncentrowało się bowiem na latach bezpośrednio powojennych oraz na okresie powstania Solidarności i obowiązywania stanu wojennego w PRL. W ten sposób wytworzyła się pewnego rodzaju luka badawcza. Dotychczasowe badania w polskiej historiografii koncentrowały się na historii politycznej oraz historii gospodarczej, szczególną wagę przywiązywano zaś do dziejów demokratycznej opozycji politycznej i historii Kościoła. Z literatury naukowej podejmującej powyższe wątki należy wymienić m.in. prace Grzegorza Waligóry ${ }^{1}$, Pawła Sasanki ${ }^{2}$,

* Doktor habilitowany, profesor nadzwyczajny UZ, Uniwersytet Zielonogórski, Instytut Historii, Zakład Historii Najnowszej.

1 G. Waligóra, ROPCiO, Warszawa 2006, s. 131-147.

2 P. Sasanka, Czerwiec 1976: geneza, przebieg, konsekwencje, Warszawa 2006.; idem, Punkt zwrotny dekady Gierka, „Wiadomości Historyczne” 2004, nr 5, s. 3-19; idem, S. Stępień, Czerwiec 1976. Radom, Ursus, Płock, Warszawa 2006. 
Jana Żaryna ${ }^{3}$, Henryka Słabka ${ }^{4}$, Andrzeja Friszkego ${ }^{5}$, Jerzego Eislera ${ }^{6}$, Marka Golińczaka $^{7}$, Łukasza Kamińskiego ${ }^{8}$. Z literatury przedmiotu pośrednio badającej zagadnienie opozycji politycznej (np. z punktu widzenia analizy społeczeństwa polskiego i jego nastrojów w tej dobie czy kryzysu w łonie władz partyjno-państwowych) nawarto wskazać m.in. opracowania wspomnianych: Jerzego Eislera ${ }^{9}$ i Andrzeja Friszkego $^{10}$, Antoniego Dudka ${ }^{11}$, Łukasza Dwilewicza ${ }^{12}$, Stanisława Gomułki ${ }^{13}$, Grażyny

3 J. Żaryn, Dzieje Kościoła katolickiego w Polsce (1944-1989), Warszawa 2003.

4 H. Słabek, Kościót katolicki w Polsce 1945-1989; „Dzieje Najnowsze” 2005, nr 1, s. 113 139. Autor ten jako jeden z pierwszych zajął się próbą analizy społeczeństwa polskiego. Zob. idem, O społecznej historii Polski 1945-1989, Warszawa 2009; idem, Chłopi-Robotnicy, Robotnicy-Chłopi, Robotnicy-Działkowicze (1945-1989), „Kwartalnik Historyczny" 2002, nr 2.

5 A. Friszke, Czas KOR-u. Jacek Kuroń a geneza Solidarności, Kraków 2011; idem, Koło posłów „Znak” w Sejmie PRL, 1957-1976, Warszawa 2002; idem, Opozycja polityczna w PRL 1945-1980, Londyn 1994; idem, Przystosowanie i opór. Studia z dziejów PRL, Warszawa 2007.

6 J. Eisler, „Polskie miesiace” czyli kryzys(y) w PRL, Warszawa 2008; idem, Grudzień 1970. Geneza, przebieg, konsekwencje, Warszawa 2000, wyd. II rozszerzone 2012; idem, A. Friszke, Wzlot i upadek ojca narodu. Dekadę Gierka oceniaja historycy: doc. Jerzy Eisler i dr Andrzej Friszke, „Życie Warszawy” 1994, 12.07.

7 M. Golińczak, Polska opozycja polityczna lat siedemdziesiątych $i$ osiemdziesiątych XX wieku wobec przeobrażeń wewnętrznych i polityki zagranicznej Związku Radzieckiego, „Pamięć i Sprawiedliwość” 2010, nr 1.

8 Ł. Kamiński, Władza wobec opozycji 1976-1989, „Pamięć i Sprawiedliwość” 2003, nr 2.

9 J. Eisler, W poszukiwaniu straconego czasu. Dekada Gierka: jaki byt naprawdę? [z Prof. J. Eislerem rozmawia D. Rafalska], „Tygodnik Powszechny” 2007, nr 22, s. 26; idem, Zmarnowana dekada, „Rzeczpospolita” 2001, 4-5.08.; idem, Siedmiu wspaniałych, Warszawa 2014; idem, Zmiany kierownictw partyjnych w PRL, [w:] Władza w PRL. Ludzie i mechanizmy, K. Rokicki, R. Spałek (red.), Warszawa 2011.

10 A. Friszke, Polska Gierka, Warszawa 1995; idem, Polska Gierka, „Mówią Wieki” 1995, nr 2; idem, Czas KOR-u...; idem, Polska. Losy państwa i narodu 1939-1989, Warszawa 2003.

11 A. Dudek, Upadek Edwarda Większego, „Wprost” 2006, nr 33/34; idem, PRL bez makijażu, Kraków 2008; idem, T. Marszałkowski, Walki uliczne w PRL 1956-1989, Kraków 1992.

12 Ł. Dwilewicz, Kupowanie poparcia. Polityka gospodarcza jako środek stabilizacji sytuacji wewnętrznej w Polsce w pierwszych miesiącach rządów Edward Gierka, „Pamięć i Sprawiedliwość" 2008, nr 2.

13 S. Gomułka, Sytuacja gospodarcza Polski $w$ drugiej połowie lat siedemdziesiatych, „Aneks” 1979, nr 21; idem, Obecna sytuacja gospodarcza w Polsce, „Kultura” (Paryż) 1975 , nr 11. 
Gradzińskiej $^{14}$, Marcina Zaremby ${ }^{15}$, Tadeusza Kijonki ${ }^{16}$, Andrzeja Krajewskiego ${ }^{17}$, Przemysława Wójcika ${ }^{18}$, Krzysztofa Dubińskiego ${ }^{19}$.

Jak jednak pisał w połowie lat 90 . wybitny polski socjolog i historyk idei Jerzy Szacki:

Potrzebne są [dwie] różne historie PRL: historia polityczna, opowiadająca o tym, co działo się z systemem politycznym, i historia społeczna, traktująca o tym, jak żyło społeczeństwo, poddane jego ciśnieniu, ale zajęte nade wszystko swymi „małymi” sprawami. Oczywiście, całkowite rozdzielenie tych dwóch historii nie jest możliwe. Niezbędne wydaje się jednak podjęcie próby oddzielenia projektu ideologicznego i jego realizacji od rzeczywistego działania społecznego żywiołu. Do tej pory historia PRL to niemal wyłącznie historia polityczna i ideologiczna ${ }^{20}$.

Historia społeczna Polski Ludowej wciąż czeka na swoje kompleksowe opracowanie. Od wielu lat toczy się żywa dyskusja na temat znaczenia awansu społecznego w interesującej nas dekadzie. Teza o znaczącym skoku cywilizacyjnym jest torpedowana przez zarzuty sprzeniewierzenia funduszy pochodzących z przyznanych Polsce kredytów zagranicznych, a przez to zaprzepaszczenie szansy na prawdziwą modernizację kraju.

Od momentu dojścia do władzy w Polsce Edwarda Gierka minęło już 45 lat. Jest to już na tyle rozległy okres historyczny, aby mówić o kilku nurtach w historiografii poświęconych dekadzie lat 70. w naszym kraju. W ciągu tego okresu mieliśmy do czynienia z dwoma narracjami (dyskursami) traktującymi o dekadzie przyspieszonego rozwoju. Pierwszy z nich miał charakter pozytywny, niekiedy wręcz apologetyczny. Drugi zaś negatywny, mniej bądź bardziej krytyczny. Dyskursy te czasem funkcjonowały równolegle obok siebie. W zasadzie jednak można dokonać ich segregacji pod względem chronologicznym Takich podokresów w literaturze naukowej i popularnonaukowej można wyodrębnić cztery. Poniżej przystąpimy do krótkiej charakterystyki każdego z nich.

14 G. Gradzińska, Chłopi wobec kryzysów społeczno-politycznych w Polsce (1944-1989), Poznań 1993.

15 M. Zaremba, Bigosowy socjalizm dekady Gierka, „Więź” 2003, nr 5; idem, Komunizm, legitymizacja, nacjonalizm. Nacjonalistyczna legitymizacja władzy komunistycznej w Polsce, Warszawa 2001; idem, Od wojny domowej do solidarnościowej rewolucji, czyli społeczeństwo nieprzedstawione dekady lat siedemdziesiątych, „Res Publica Nowa” 2000, nr 8.

16 T. Kijonka, Między Zachodem a Wschodem. Dekada Edwarda Gierka, „Śląsk” 2001, nr 9.

17 A. Krajewski, Między współpraca a oporem. Twórcy kultury wobec systemu politycznego PRL (1975-1980), Warszawa 2004.

18 P. Wójcik (red.), Elity władzy w Polsce a struktura społeczna w latach 1956-1981, Warszawa 1994.

19 K. Dubiński, Rewolta radomska. Czerwiec 76, Warszawa 1991.

20 Cyt. za: H. Słabek, O społecznej historii..., s. 12. 
Pierwszy okres narracji na temat epoki gierkowskiej lokuje się w trakcie trwania dekady przyspieszonego rozwoju i kończy się wraz z protestami z lata 1980 roku. Abstrahując od medialnej propagandy sukcesu, mającej ukazać same superlatywy związane z nowymi władzami, w polskiej historiografii zaczęły się pojawiać opracowania próbujące na bieżąco dokonywać podsumowania pierwszych lat rządów ekipy Gierka. Pierwszą datą ramową, która stała się okazją do skromnego bilansu były obchody trzydziestolecia „odrodzenia” Polski, przypadające na 1974 rok. W wydawnictwach o charakterze syntetycznym na temat historii Polski podjęto próby oceny pierwszych czterech lat nowej władzy. Jednym z takich sztandarowych opracowań była synteza Władysława Góry, w której autor niezwykle pozytywnie odniósł się do ostatnich reform społeczno-ekonomicznych w kraju ${ }^{21}$. Od połowy dekady ukazywała się też seria wydawnictw monograficznych poświęconych wyłącznie przemianom, jakie w ostatnich latach dokonywały się na oczach obywateli. Możemy wymienić tu chociażby monografie Franciszka Kubiczka ${ }^{22}$ czy Adama Pużyńskiego ${ }^{23}$. Narracja tych prac była w zasadzie jednostronna, głosiła hurraoptymizm przeplatany $\mathrm{z}$ propagandą sukcesu. Polska jawiła się w nich jako kraj mlekiem i miodem płynący, właśnie dzięki nowej polityce Edwarda Gierka, związanej z otwarciem Polski na świat i modernizacją polityki społeczno-ekonomicznej. Opracowania te aż roją się od statystyk, które w założeniu autorów magią liczb miały porwać czytelników, przekonując ich, że reformy, które się właśnie dokonują są kluczowe w dziejach Polski i przyczyniają się do stworzenia, jak to wówczas lansowano, „dziesiątej potęgi ekonomicznej świata”. Spory nacisk w narracji kładziono na podkreślenie prospołecznego charakteru nowej władzy, zainteresowanej awansem kulturowo-cywilizacyjnym narodu polskiego. W objętym analizą okresie praktycznie nie mieliśmy do czynienia z przeciwnym dyskursem w oficjalnym obiegu wydawniczym. Nie znaczy to, rzecz jasna, iż nurt takowy nie istniał poza nim. Krytyczne głosy zamieszczane były na łamach, z jednej strony wydawnictw emigracyjnych, a $\mathrm{z}$ drugiej krajowych wydawnictw drugoobiegowych. Te pierwsze, skupione wokół periodyków „Kultura” i „Aneks”, starały się ukazać społeczeństwu obłudę nowych władz i obnażać negatywne aspekty życia społecznego. Z licznych opracowań naukowych wystarczy chociażby wspomnieć o analizach ekonomicznych Stanisława Gomułki, które wskazywały na nadchodzący kryzys, pokazując błędy niedbałej i niekonsekwentnej polityki

21 W. Góra, Polska Rzeczpospolita Ludowa, Warszawa 1974.

22 Społeczno-gospodarczy rozwój Polski w latach 1971-1975, F. Kubiczek (red.), Warszawa 1975.

23 A. Pużyński, Rozwój społeczno-gospodarczy Polski w latach siedemdziesiątych, Warszawa 1978. 
centralnego planowania ${ }^{24}$. W kraju największą aktywność wydawniczą związaną z narracją krytyczną względem dekady gierkowskiej podjęly wydawnictwa podziemne, związane z Komitetem Obrony Robotników oraz Ruchem Obrony Praw Człowieka i Obywatela ${ }^{25}$. Po czerwcu 1976 roku ów nurt krytyczny skupił się na wyeksponowaniu wciąż policyjnego i represyjnego charakteru państwa, momentami wręcz nawołując do protestu społecznego bądź rewolucji.

$\mathrm{Na}$ fali podpisania porozumień sierpniowych i odejścia od władzy Edwarda Gierka przystąpiono do coraz odważniejszej krytyki polityki byłego I sekretarza. Okres „karnawału Solidarności” wprowadził do oficjalnego obiegu publikacje o charakterze krytycznym, rozpoczynając w ten sposób drugi podokres w historiografii dekady gierkowskiej. Na Walnym Zgromadzeniu Delegatów Polskiego Towarzystwa Historycznego w Zielonej Górze 22.09.1980 roku ogłoszono wręcz wolność badań historycznych. Od samego hasła jednak daleka była jeszcze droga do jego pełnej realizacji. Wprowadzenie stanu wojennego w Polsce wiązało się z internowaniem wysokich prominentów, w tym samego Gierka. Ekipa Wojciecha Jaruzelskiego potrzebowała „kozła ofiarnego”, aby obwinić kogoś za katastrofalną sytuację gospodarczą kraju. Gierek wydawał się idealną postacią, dlatego publikacje naukowe, które pojawiały się w latach 80. XX wieku nie stroniły od licznych akcentów krytycznych, związanych z dekadą przyspieszonego rozwoju. W najlepszym wypadku historiografia lat 80 . była po prostu zdystansowana do poprzedniego dziesięciolecia, odmawiając mu prawa do bycia znaczącym podokresem w historii kraju. Z tego typu oficjalnych opracowań możemy przywołać syntezę dziejów politycznych Polski pod redakcją Tadeusza Walichnowskiego ${ }^{26}$ oraz krytyczny dyskurs w badaniach historyków gospodarczych, takich jak np. Zbigniew Landau ${ }^{27}$. Ów dyskurs daje się sprowadzić do obwinienia poprzedniej władzy za gigantyczne zadłużenie kraju, nierentowne inwestycje, korupcję, układy i marnotrawstwo funduszy państwowych oraz oczywiście zwrócenia uwagi na konsekwencje tych działań w postaci problemów aprowizacyjnych na rynku.

24 S. Gomułka, Ekonomiczne motywy czerwcowego buntu, „Aneks” 1976, nr 12; idem, Obecna sytuacja gospodarcza..., s. 90-107; idem, Sytuacja gospodarcza Polski w drugiej połowie lat siedemdziesiątych, „Aneks” 1979, nr 21, s. 15-33; idem, VII Zjazd PZPR: Uwagi do planu 1976-80, „Aneks” 1976, nr 11.

25 Zob. np. J. Szczęsna, W kościele św. Marcina, „Zapis” 1977, nr 4; A. Kowalska, Piękni dwudziestoletni, „Biuletyn Informacyjny” 1979, nr 3.

${ }^{26}$ Z dziejów politycznych Polski 1944-1984, H. Dominiczak, R. Halaba, T. Walichnowski (red.), Warszawa 1984.

27 I. Kostrowicka, Z. Landau, J. Tomaszewski, Historia gospodarcza Polski XIX i XX wieku, Warszawa 1984. 
Przemiany ustrojowe w Polsce wywołane obradami Okrągłego Stołu przyniosły niespotykaną do tej pory wolność i swobodę w narracji historycznej. Rzecz jasna, nie ominęła ona również epoki gierkowskiej. W tym momencie niejako drogą kontrastu w stosunku do rządów reżimu Jaruzelskiego zaczęto postrzegać lata 70. bardziej pozytywnie, jako względnie spokojny okres, choć niepozbawiony błędów i wypaczeń, których symbolami stało się zadłużenie kraju oraz poradomskie represje. Tym samym rozpoczął się kolejny, trzeci podokres w interesującej nas historiografii. Brak cenzury i możliwość swobodnej wypowiedzi zrodziły nowy nurt, wywołany masowym „wysypem” relacji pamiętnikarskich byłych prominentów, którzy podjęli się próby obrony swoich dokonań w dekadzie gierkowskiej. Nagle Edward Gierek ${ }^{28}$, Piotr Jaroszewicz ${ }^{29}$, Edward Babiuch $^{30}$, Stanisław Kania ${ }^{31}$, Józef Tejchma ${ }^{32}$, Franciszek Szlachcic ${ }^{33}$, Kazimierz $\mathrm{Kąkol}^{34}$, Włodzimierz Janiurek ${ }^{35}$ rzucili się do piór i maszyn, aby ukazać „prawdziwe” oblicze i motywy swoich działań. Wywiady z „towarzyszem Edwardem", przeprowadzone przez dziennikarza Janusza Rolickiego (Przerwana dekada ${ }^{36}$ i Replika ${ }^{37}$ ), stały się bestsellerami na polskim rynku, sprzedanymi w milionowych nakładach. Sam Gierek podjął się napisania autobiografii, która ukazała się w 1993 roku pt. Smak życia ${ }^{38}$. We wszystkich wspomnianych publikacjach śląski włodarz jawi się jako mąż opatrznościowy, idealny przywódca, człowiek skromny i pracowity, a swoje decyzje przedstawia jako owoc wielotygodniowych demokratycznych konsultacji z gronem ekspertów, specjalistów i polityków. Zdaniem Gierka, taka polityka była konieczna, wielomilionowe kredyty zostałyby „w mig” spłacone, gdyby nie symboliczne „przerwanie” dekady przez Solidarność i późniejsze rządy niesławnego generała, który zmarnował dorobek budowania „Drugiej Polski”. Rzecz jasna, inni prominenci w swe wspomnienia, oprócz gloryfikacji dekady lat 70., wplatali głosy krytyczne na temat byłego I sekretarza, chcąc usprawiedliwić czy wytłumaczyć swoje decyzje i prowadzoną politykę, żeby wymienić tu chociażby

28 Gierek \& Jaroszewicz zeznają, E. Desperak, M. Domański (red.), Warszawa 1990.

29 P. Jaroszewicz, B. Roliński, Przerywam milczenie... 1939-1989, Warszawa 1991.

30 M. Zieleniewski, Przez lekko uchylona bramę: Gierek, Jaroszewicz, Babiuch, Cyrankiewicz, Szlachcic i inni, Kościan 1989.

31 S. Kania, Zatrzymać konfrontacje, Warszawa 1991.

32 J. Tejchma, Kulisy dymisji. Z dzienników ministra kultury 1974-1977, Kraków 1991; idem, Pożegnanie z władza, Warszawa 1996.

33 F. Szlachcic, Gorzki smak władzy, Warszawa 1990.

34 K. Kąkol, Spowiedź pogromcy Kościoła, Olsztyn 1994.

35 W. Janiurek, Nie wołać mnie z powrotem, Katowice 1991.

36 J. Rolicki, Edward Gierek - przerwana dekada. Wywiad rzeka, Warszawa 1990.

37 J. Rolicki, Edward Gierek. Replika - prawda do końca..., Warszawa 1990.

38 E. Gierek, Smak życia. Pamiętniki, Warszawa 1993. 
tylko reminiscencje PRL-u w książkach Franciszka Szlachcica czy Piotra Jaroszewicza. W ich relacjach Gierek nie jawi się już jako skromny demokrata, lecz apodyktyczny przywódca niezdolny do ustępstw. Należy jednak mieć na uwadze, że narracje retrospektywne (pamiętniki i dzienniki) trudno traktować jako historiografię, dlatego powinniśmy skupić się na monografiach i syntezach. W latach 90. pojawiły się też pierwsze naukowe i popularnonaukowe syntezy interesującej nas dekady. Sztandarową jest wydana w 1995 roku Polska Gierka autorstwa znanego historyka Andrzeja Friszkego ${ }^{39}$. W syntezie tej osąd nie jest jednoznaczny, autor wyodrębnia bowiem zarówno negatywy, jak i pozytywy minionej epoki, starając się zobiektywizować swoją ocenę. Przez samą pracę przebija jednak nutka pozytywnej narracji, co jest subiektywnym wrażeniem piszącego te słowa. Z tym delikatnie sentymentalno-pozytywnym odcieniem wiąże się prawdopodobnie stare prawidło oceny dawnych czasów przez pryzmat własnej młodości. Otóż, nie odmawiając wiodącym polskim historykom obiektywizmu, czasy gierkowskie przypadały na ich młodość, która zawsze jest, świadomie bądź podświadomie, upiększana, żeby zacytować tu tylko narodowego wieszcza: „Kraj lat dziecinnych! On zawsze zostanie Święty i czysty jak pierwsze kochanie" ${ }^{40}$ czy ministra Charles-Maurice’a Talleyranda: „Kto nie żył przed rewolucją, nie żył wcale”. Czytając liczne naukowe opracowania, odnosi się również wrażenie, że jeszcze brak im dystansu do opisywania dekady, która zakończyła się raptem w roku 1980. Podobne akcenty możemy znaleźć bowiem również w innych opracowaniach, które nie były jednak syntezami dekady przyspieszonego rozwoju, choć poświeciły jej mniejsze bądź większe fragmenty narracji historycznej ${ }^{41}$.

Śmierć sędziwego Edwarda Gierka w roku 2001 wywołała lawinę artykułów prasowych poświęconych „przerwanej dekadzie” pisanych przez zawodowych historyków. Wraz z tym procesem ruszył dyskurs umiarkowanie krytyczny, mający wykazać nieudolność polityki lat 70., co doskonale oddaje sam tytuł artykułu znanego historyka Jerzego Eislera $A$ jednak zmarnowana dekada ${ }^{42} . \mathrm{Na}$ obronę Edwardowi Gierkowi ruszył wspomniany wcześniej Janusz Rolicki, wydając popularnonaukową, pierwszą biografię śląskiego sekretarza. Dawny przywódca partyjno-państwowy jest w niej oceniany zdecydowanie pozytywnie,

39 A. Friszke, Polska Gierka, Warszawa 1995. Por. J. Eisler, A. Friszke, Wzlot i upadek ojca narodu...

40 A. Mickiewicz, Pan Tadeusz czyli Ostatni zajazd na Litwie: historia szlachecka $z$ roku 1811 i 1812 we dwunastu ksieggach wierszem, Warszawa 1982, s. 618.

41 A. Czubiński, Dzieje najnowsze Polski: Polska Ludowa (1944-1989), Poznań 1992; J. Kuroń, J. Żakowski, PRL dla początkujacych, Wrocław 1995.

42 J. Eisler, A jednak zmarnowana dekada, „Rzeczpospolita” 2001, 20.08., s. 8. Zob. też: idem, W poszukiwaniu straconego czasu...; idem, Zmarnowana dekada. 
a monografia ta ociera się momentami o hagiografię ${ }^{43}$. W 1999 roku w Polsce powstał Instytut Pamięci Narodowej, którego jednym z głównych zadań jest wypełnienie „białych plam” w historii najnowszej ${ }^{44}$. Dyskurs zapoczątkowany przez historyków związanych z IPN-em był dla Gierka i jego epoki nieprzychylny. W opracowaniach Łukasza Kamińskiego ${ }^{45}$ czy Antoniego Dudka ${ }^{46}$ ewidentnie przebija krytycyzm wobec dekady i jej odbrązowienie. Eksponuje się represje, a względna liberalizacja systemu określana bywa mianem „wentylu bezpieczeństwa”, koniecznego dla przetrwania reżimu. Takie podejście zaznacza się też w pierwszej poważnej syntezie radomskiego czerwca autorstwa młodego historyka Pawła Sasanki, wydanej w 2006 roku ${ }^{47}$.

W 2009 roku opublikowane zostały interesujące wspomnienia bliskiego współpracownika Gierka z tego trudnego okresu, który odbył z nim kilka długich rozmów od września do grudnia roku 1981, a potem przez jakiś czas był razem z nim internowany. To Wiesław Kiczan, w latach 1962-1971 pełniący funkcję sekretarza KW PZPR w Katowicach (bezpośrednio współpracujący wtedy z Gierkiem), a od 1976 do 1981 roku wiceminister górnictwa i energetyki ${ }^{48}$. W świetle własnych wypowiedzi, przytaczanych przez Kiczana, śląski włodarz sam stał się ofiarą systemu komunistycznego i osobą represjonowaną - choć oczywiście był to jego subiektywny ogląd rzeczywistości. Przypominał zarzuty o nadużyciach finansowych, zapewniając, że to „pretekst kłamliwy od początku do końca, żeby nas publicznie oczerniać, grać na ludzkich emocjach”. Rozżalony dodawał: „I nie dziwiłbym się, gdyby robili to ci z »Solidarności«. Ale swoi?"49. Czuł się chory, odnowiła mu się dawna pylica i uraz kręgosłupa ${ }^{50}$. Jak twierdził, już w końcu lat 70. odczuwał zmęczenie, dokuczały mu choroby i sam się zastanawiał, czy nie ustąpić ${ }^{51}$. Kiczan wspomina, że od początku 1980 roku „docierały wieści, że [Gierek] częściej przebywa w domu niż w pracy”, mogło to być spowodowane chorobami, ale też „spadkiem odporności

43 J. Rolicki, Edward Gierek. Życie i narodziny legendy, Warszawa 2002.

44 Por. J. Eisler, Grudzień 1970. Geneza, przebieg, konsekwencje, Warszawa 2012, s. 9.

45 Opozycja demokratyczna w działaniach władz PRL [dyskusja z 3.06.2003 r. odbyta przez Łukasza Kamińskiego, Antoniego Dudka, Jerzego Eislera, Andrzeja Friszke, Henryka Głębockiego i Grzegorza Waligórę], „Pamięć i Sprawiedliwość” 2003, nr 2.

46 A. Dudek, Upadek Edwarda Większego.

47 P. Sasanka, Czerwiec 1976: geneza, przebieg, konsekwencje. Zob. też: idem, Punkt zwrotny dekady Gierka; idem, S. Stępień, Czerwiec 1976. Radom, Ursus, Płock; P. Sasanka, R. Spałek (red.), 1976. Spory i refleksje po 25 latach, Warszawa 2003.

48 W. Kiczan, Gierek, Jaroszewicz, Wojtyła... Sekrety spisane podczas internowania, Sosnowiec 2009.

49 Ibidem, s. 12.

50 Ibidem, s. 35.

51 Ibidem, s. 36. 
psychicznej na potęgujące się trudności”’52. Był rozgoryczony. Rozpamiętywał przyczyny swego upadku, oskarżał współpracowników o wprowadzanie go wbłąd co do rozmiarów protestu społecznego latem 1980 roku. Wspominał, że w tym okresie codziennie rozmawiał z ministrem spraw wewnętrznych Stanisławem Kowalczykiem ${ }^{53}$, który „twierdził, że da się te konflikty spokojnie rozładować”, podobnie uspokajał go Stanisław Kania ${ }^{54}$. Zapewniał, że sam chciał wprowadzić w życie część postulatów gospodarczych, a nawet politycznych, formułowanych przez nielegalną opozycję działającą w końcu lat 70., tylko brakło mu czasu ${ }^{55}$. Jakby w sprzeczności z tym, mówił też o braku akceptacji ze strony Kremla. W warunkach ograniczonej suwerenności, jaką dysponowała Polska w tym czasie, warszawskie kierownictwo miało bardzo ograniczony zakres samodzielnego podejmowania decyzji. Jeśli Gierek rzeczywiście chciał reformować Polskę, to oczywiście musiałby uzyskać zgodę Moskwy, na co ze strony Leonida Breżniewa i jego ekipy raczej trudno było liczyć. Jednak, tak jak już wcześniej odnotowano, wspomnienia jako źródła historycznego nie sposób zaliczyć do historiografii sensu stricto, dlatego wróćmy do rozważań na gruncie naukowym.

Drugą dekadę XXI wieku cechuje powrót do sentymentalno-pozytywnego dyskursu. Grono dawnych prominentów, takich jak Paweł Bożyk, stara się, w przeciwieństwie do początku lat 90. wykazać na gruncie naukowym, że rządy Edwarda Gierka były korzystne dla Polski, i że w obecnej Polsce politycy i ekonomiści mogliby się wręcz uczyć od ekipy dawnych technokratów ${ }^{56}$. Okres ten obfitował w liczne konferencje i seminaria poświęcone epoce gierkowskiej, a w mediach pojawiały się głosy o postulatach ogłoszenia roku 2013 rokiem Edwarda Gierka. O pozytywny PR ojca dba też jego syn, profesor Adam Gierek, w swoich licznych wypowiedziach i publikacjach. Nie znaczy to jednak, iż przeminął nurt krytyczny. Dyskusja wśród historyków trwa nadal i ciężko o jej jednoznaczne rozstrzygnięcie. Na uwagę zasługują ostatnie opracowania poświęcone opozycji lat 70. i warunkom jej działania w ówczesnej Polsce, co rzuca też światło na ówczesne stosunki polityczne. $Z$ wiodących prac na ten

52 Ibidem, s. 16.

53 W Przerwanej dekadzie Edward Gierek określił ministra Kowalczyka jako największą pomyłkę kadrową swojego życia. J. Rolicki: Edward Gierek: przerwana dekada..., s. 206-207.

54 W. Kiczan, op. cit., s. 16. Ale ze wspomnień Czesława Kiszczaka, który był wtedy bezpośrednim podwładnym Kani i utrzymywał z nim stały kontakt, wynika, że Kania autentycznie wierzył w to, co przekazywał Gierkowi - że konflikt, nie jest groźny, strajki da się łatwo opanować - W. Bereś, J. Skoczylas, C. Kiszczak, Generał Kiszczak mówi prawie wszystko, Warszawa 1991, s. 105.

55 W. Kiczan, op. cit., s. 17.

56 P. Bożyk, Cywilizacyjne skutki otwarcia Polski na Zachód, Warszawa 2011. 
temat należałoby wymienić Czas KOR-u Andrzeja Friszkego ${ }^{57}$ oraz Siłę bezsilnych Jana Skórzyńskiego ${ }^{58}$. Ostatnio monografią tyczącą się interesującej nas dekady jest kolejna popularnonaukowa biografia Edwarda Gierka pióra Piotra Gajdzińskiego ${ }^{59}$. Można ją zdecydowanie uznać za przejaw nurtu krytycznego w polskiej historiografii dotyczącej lat 70., jak i samego Gierka, stanowi więc swoistą przeciwwagę dla dzieła Janusza Rolickiego sprzed 12 lat.

Również piszący te słowa w okresie 2009-2015 opublikował kilkanaście artykułów na temat Polski lat 70. XX wieku, włączając się przez to w dyskurs naukowy dotyczący tej niezwykle interesującej dekady. Na ile plasują się one w nurcie krytycznym, a na ile hagiograficznym autor pozostawia ocenom innych badaczy ${ }^{60}$.

Podsumowując powyższe rozważania, należy stwierdzić, że w ostatnich czterech dekadach funkcjonowały dwie narracje historyczne na temat okresu

57 A. Friszke, Czas KOR-u...

58 J. Skórzyński, Siła bezsilnych. Historia Komitetu Obrony Robotników, Warszawa 2012.

59 P. Gajdziński, Gierek... człowiek z węgla, Poznań 2014.

60 R. Domke, „Byt ksztattuje świadomość”. Wplyw forsownej polityki inwestycyjnej na przemiany społeczne w Polsce w latach 70-tych XX wieku, [w:] Poczucie bezpieczeństwa obywateli państw Europy Środkowej w latach 1971-1981. Zbiór studiów, J. Farysej, H. Lisiak, K. Siemaszko (red.), Poznań 2012; idem, Otwarcie Polski na Europę w polityce zagranicznej Edwarda Gierka 1970-1980, [w:] Człowiek w Europie. O polityce, która rządzi losami człowieka, M. Frantz, K. Kościelniak (red.), Toruń 2011; idem, Problemy społeczne Polaków w świetle analiz Biura Listów KC PZPR w latach siedemdziesiątych XX wieku, „Pamięć i Sprawiedliwość” 2011, nr 1; idem, Propaganda sukcesu w prasie elementem ksztattowania wizerunku Polski lat 70., jako dziesiątej potęgi ekonomicznej świata, [w:] Bibliologia polityczna. Nauka, dydaktyka, praktyka, D. Kuźmina (red.), Warszawa 2011; idem, Stosunki państwo - Kościół w Polsce w latach 70. XX wieku. Mit normalizacji a rzeczywistość historyczna, [w:] Mity historyczno-polityczne. Wyobrażenia zbiorowe. Polityka historyczna. Studia i materiały, t. 2, E. Ponczek, A. Sepkowski, M. Rekść (red.), Toruń 2013; idem, Zmiana stylu funkcjonowania elit politycznych w Polsce w okresie rzadów Edwarda Gierka, [w:] Oblicza utopii, obłudy i zakłamania, W. Łysiak (red.), Poznań 2013; idem, Przemiany społeczne polskiej opozycji w latach 70. XX wieku, [w:] Współczesne i historyczne konteksty wolności, L. Kopciuch (red.), Lublin 2013; idem, Przemiany wartości i postaw społeczeństwa polskiego w dobie gierkowskiej, [w:] Oblicza utopii, obłudy i zakłamania, t. 2, W. Łysiak (red.), Poznań 2014; idem, Film polski lat 70. a rzeczywistość społeczna, [w:] Poczucie bezpieczeństwa Polaków w dekadzie gierkowskiej. Bezsilność i zmęczenie, antropologia codzienności w latach 70., J. Farysej, H. Lisiak, K. Siemaszko (red.), Poznań 2014; idem, Wpływ wydarzeń międzynarodowych na przemiany społeczne w Polsce lat 70., „Racja Stanu” 2012-2013, nr 1-2; idem, Przemiany modelu społeczno-kulturowego polskiej rodziny wiejskiej, „Forum Historyczno-Społeczne” 2014, nr 2; idem, Polska emigracja polityczna wobec problemów kraju w latach 70. XX wieku, „Przegląd Polsko-Polonijny” 2014, nr 7-8; idem, Kształcenie dzieci i młodzieży w Polsce w latach 70. XX wieku, „Studia Zachodnie” 2015, t. 17. 
rządów Edwarda Gierka: pozytywna i negatywna. Samą historiografię możemy natomiast podzielić na cztery podokresy chronologiczne: 1) piśmiennictwo historyczne powstałe jeszcze $\mathrm{w}$ trakcie trwania dekady gierkowskiej; 2) opracowania historyczne $\mathrm{z}$ lat 80 . XX wieku; 3) narracje powstałe w ostatniej dekadzie poprzedniego stulecia, po przemianach 1989 roku; 4) dyskurs stosowany od śmierci Gierka w 2001 roku po dziś dzień. Autor zdaje sobie sprawę, jak bardzo te przedziały są umowne i jest gotowy podjąć polemikę na temat ich ewentualnego przekonstruowania. Nie zmienia to jednak faktu, że jakbyśmy nie podzielili tych kilku ostatnich dekad, to cechowały się one współistnieniem powyższych dwóch dyskursów: pozytywnego (apologetycznego) oraz negatywnego (krytycznego). Dyskursy te uzależnione były od danej sytuacji politycznej, a nawet od bieżących potrzeb polityczno-marketingowych ${ }^{61}$, nie zawsze należy jednak bezpośrednio je z nimi utożsamiać.

Ponadto cezurę $\mathrm{z}$ historii politycznej $\mathrm{w}$ znacznym stopniu możemy też odnieść do historii społecznej. Po roku 1976 rosło bowiem niezadowolenie społeczne i poczucie niepewności oraz rozżalenia. Wybuchowa energia społeczna ulegała daleko idącej kumulacji, czekając na pretekst do jej uwolnienia, jakim stała się podwyżka cen latem 1980 roku. W ten sposób społeczeństwo polskie jako struktura w ujęciu dynamicznym wykazywało pewną dwoistość w aspekcie świadomości społecznej. W pierwszej połowie dekady cechowało się bowiem optymizmem, nadzieją i pozytywną energią społeczną, w drugiej zaś zniechęceniem, rozżaleniem, apatią oraz społeczną frustracją. W kontekście świadomości społecznej wydaje się to zasadniczą przemianą, odczuwalną w procesie długiego trwania. Podobne zależności da się również uchwycić w tonie piśmiennictwa historycznego na temat interesującej nas dekady. Występuje tutaj zależność wprost proporcjonalna. Jeżeli analizowane są lata 1971-1975, statystycznie częściej występuje dyskurs pozytywny, jeżeli 1976-1980, dyskurs negatywny. Historycy są tutaj w zasadzie zgodni, co do cezury 1976 roku, chociaż symptomy kryzysu dostrzegają już znacznie wcześniej, w 1975, a czasem nawet w 1974 roku.

Na koniec rodzi się pytanie, czy któryś z nurtów na tyle zdominował ostatnie 35-40 lat, że możemy mówić o negatywnym bądź pozytywnym wizerunku dekady gierkowskiej w polskiej historiografii? Odpowiedź wydaje się przecząca, albowiem powyższe rozważania wyraźnie ukazują nam, iż dyskurs historyczny na temat lat 70. płynie dwoma następującymi po sobie falami, z których żadna trwale nie nachodzi na drugą. Nawet jeżeli daje się wyodrębnić

${ }^{61}$ Jako przykład przytoczyć należy wypowiedź Jarosława Kaczyńskiego z 2010 roku w trakcie kampanii wyborczej, w której pozytywnie wyraził się on o śląskim włodarzu, aby pozyskać głosy elektoratu lewicy. P. Gajdziński, op. cit., s. 365-366. 
charakterystyczne podokresy, trwające 7-10 lat, w których dominuje pochwała bądź krytyka dekady, to również w ich ramach funkcjonują te dwa punkty widzenia (może za wyjątkiem lat 80., kiedy naprawdę trudno doszukać się pozytywnych opracowań na temat poprzedniego dziesięciolecia w Polsce). Na tej konstatacji musimy poprzestać, czekając, aż kolejne lata, miejmy nadzieję płodne w opracowania historyczne, zweryfikują bądź nie, odpowiedź na powyższe pytanie.

\section{Bibliografia}

Bożyk P., Cywilizacyjne skutki otwarcia Polski na Zachód, Warszawa 2011.

Czubiński A., Dzieje najnowsze Polski: Polska Ludowa (1944-1989), Poznań 1992.

Desperak E., Domański M., Gierek \& Jaroszewicz zeznaja, Warszawa 1990.

Domke R., „Byt kształtuje świadomośc”. Wplyw forsownej polityki inwestycyjnej na przemiany społeczne w Polsce w latach 70-tych XX wieku, [w:] Poczucie bezpieczeństwa obywateli państw Europy Środkowej w latach 1971-1981. Zbiór studiów, J. Farysej, H. Lisiak, K. Siemaszko (red.), Poznań 2012, s. 203-220.

Domke R., Film polski lat 70. a rzeczywistość społeczna, [w:] Poczucie bezpieczeństwa Polaków w dekadzie gierkowskiej. Bezsilność i zmęczenie, antropologia codzienności w latach 70., J. Farysej, H. Lisiak, K. Siemaszko (red.), Poznań 2014, s. 289-309.

Domke R., Kształcenie dzieci i młodzieży w Polsce w latach 70. XX wieku, „Studia Zachodnie" 2015, t. 17, s. 239-261.

Domke R., Otwarcie Polski na Europę w polityce zagranicznej Edwarda Gierka 1970-1980, [w:] Człowiek w Europie. O polityce, która rzadzi losami człowieka, M. Frantz, K. Kościelniak (red.), Toruń 2011, s. 150-180.

Domke R., Polska emigracja polityczna wobec problemów kraju w latach 70. XX wie$k u$, „Przegląd Polsko-Polonijny” 2014, nr 7-8, s. 53-68.

Domke R., Problemy społeczne Polaków w świetle analiz Biura Listów KC PZPR w latach siedemdziesiątych XX wieku, „Pamięć i Sprawiedliwość” 2011, nr 1, s. 353-370.

Domke R., Propaganda sukcesu w prasie elementem ksztattowania wizerunku Polski lat 70., jako dziesiątej potęgi ekonomicznej świata, [w:] Bibliologia polityczna. Nauka, dydaktyka, praktyka, D. Kuźmina (red.), Warszawa 2011, s. 298-309.

Domke R., Przemiany modelu społeczno-kulturowego polskiej rodziny wiejskiej, „Forum Historyczno-Społeczne”, 2014, no 2, s. 77-86. 
Domke R., Przemiany społeczne polskiej opozycji w latach 70. XX wieku, [w:] Współczesne i historyczne konteksty wolności, L. Kopciuch (red.), Lublin 2013, s. 35-57.

Domke R., Przemiany wartości i postaw społeczeństwa polskiego $w$ dobie gierkowskiej, [w:] Oblicza utopii, obłudy i zakłamania, t. 2, W. Łysiak (red.), Poznań 2014, s. 239-258.

Domke R., Stosunki państwo - Kościót w Polsce w latach 70. XX wieku. Mit normalizacji a rzeczywistość historyczna, [w:] Mity historyczno-polityczne. Wyobrażenia zbiorowe. Polityka historyczna. Studia i materiaty, t. 2, E. Ponczek, A. Sepkowski, M. Rekść (red.), Toruń 2013, s. 190-206.

Domke R., Wpływ wydarzeń międzynarodowych na przemiany społeczne w Polsce lat 70., „Racja Stanu” 2012-2013, nr 1-2, s. 173-188.

Domke R., Zmiana stylu funkcjonowania elit politycznych $w$ Polsce $w$ okresie rządów Edwarda Gierka, [w:] Oblicza utopii, obłudy i zakłamania, W. Łysiak (red.), Poznań 2013, s. 323-335.

Dubiński K., Rewolta radomska. Czerwiec 76, Warszawa 1991.

Dudek A., PRL bez makijażu, Kraków 2008.

Dudek A., Upadek Edwarda Większego, „Wprost” 2006, nr 33-34.

Dudek A., Marszałkowski T., Walki uliczne w PRL 1956-1989, Kraków 1992.

Dwilewicz Ł., Kupowanie poparcia. Polityka gospodarcza jako środek stabilizacji sytuacji wewnętrznej w Polsce $w$ pierwszych miesiacach rządów Edwarda Gierka, „Pamięć i Sprawiedliwość” 2008, nr 2, s. 157-177.

Eisler J., A jednak zmarnowana dekada, „Rzeczpospolita” 2001, 20.08.

Eisler J., Grudzień 1970. Geneza, przebieg, konsekwencje, Warszawa 2000, 2012.

Eisler J., „Polskie miesiace” czyli kryzys(y) w PRL, Warszawa 2008.

Eisler J., Siedmiu wspaniałych, Warszawa 2014.

Eisler J., W poszukiwaniu straconego czasu. Dekada Gierka: jaki był naprawdę?

[z Prof. J. Eislerem rozmawia D. Rafalska], „Tygodnik Powszechny” 2007, nr 22.

Eisler J., Zmarnowana dekada, „Rzeczpospolita” 2001, 4-5.08.

Eisler J., Zmiany kierownictw partyjnych w PRL, [w:] Władza w PRL. Ludzie i mechanizmy, K. Rokicki, R. Spałek (red.), Warszawa 2011, s. 63-78.

Eisler J., Friszke A., Wzlot i upadek ojca narodu. Dekadę Gierka oceniaja historycy: doc. Jerzy Eisler i dr Andrzej Friszke, „Życie Warszawy” 1994, 12.07.

Friszke A., Czas KOR-u. Jacek Kuroń a geneza Solidarności, Kraków 2011.

Friszke A., Koło posłów „Znak” w Sejmie PRL, 1957-1976, Warszawa 2002.

Friszke A., Opozycja polityczna w PRL 1945-1980, Londyn 1994.

Friszke A., Polska Gierka, „Mówią Wieki” 1995, 2, Warszawa 1995.

Friszke A., Polska. Losy państwa i narodu 1939-1989, Warszawa 2003.

Friszke A., Przystosowanie i opór. Studia z dziejów PRL, Warszawa 2007. 
Gajdziński P., Gierek... człowiek z wegla, Poznań 2014.

Gierek E., Smak życia. Pamiętniki, Warszawa 1993.

Golińczak M., Polska opozycja polityczna lat siedemdziesiątych i osiemdziesiątych XX wieku wobec przeobrażeń wewnętrznych i polityki zagranicznej Związku Radzieckiego, „Pamięć i Sprawiedliwość” 2010, nr 1, s. 349-382.

Gomułka S., Ekonomiczne motywy czerwcowego buntu, „Aneks” 1976, nr 12, s. $20-22$.

Gomułka S., Obecna sytuacja gospodarcza w Polsce, „Kultura” (Paryż) 1975, nr 11, s. 46-54.

Gomułka S., Sytuacja gospodarcza Polski w drugiej połowie lat siedemdziesiatych, „Aneks” 1979, nr 21, s. 15-33.

Gomułka S., VII Zjazd PZPR: Uwagi do planu 1976-80, „Aneks” 1976, nr 11, s. $24-43$.

Góra W., Polska Rzeczpospolita Ludowa, Warszawa 1974.

Gradzińska G., Chłopi wobec kryzysów społeczno-politycznych w Polsce (19441989), Poznań 1993.

Janiurek W., Nie wołać mnie z powrotem, Katowice 1991.

Jaroszewicz P., Roliński B., Przerywam milczenie... 1939-1989, Warszawa 1991.

Kamiński Ł., Władza wobec opozycji 1976-1989, „Pamięć i Sprawiedliwość” 2003, nr 2, s. 9-32.

Kania S., Zatrzymać konfrontację, Warszawa 1991.

Kąkol K., Spowiedź pogromcy Kościoła, Olsztyn 1994.

Kiczan W., Gierek, Jaroszewicz, Wojtyła... Sekrety spisane podczas internowania, Sosnowiec 2009.

Kijonka T., Między Zachodem a Wschodem. Dekada Edwarda Gierka, „Śląsk” 2001, nr 9, s. 4-5, 7.

Kostrowicka I., Landau Z., Tomaszewski J., Historia gospodarcza Polski XIX i XX wieku, Warszawa 1984.

Kowalska A., Piękni dwudziestoletni, „Biuletyn Informacyjny” 1979, nr 3, s. 41-46.

Krajewski A., Między wspótpraca a oporem. Twórcy kultury wobec systemu politycznego PRL (1975-1980), Warszawa 2004.

Kubiczek F. (red.), Społeczno-gospodarczy rozwój Polski w latach 1971-1975, Warszawa 1975.

Kuroń J., Żakowski J., PRL dla poczatkujących, Wrocław 1995.

Mickiewicz A., Pan Tadeusz czyli Ostatni zajazd na Litwie: historia szlachecka z roku 1811 i 1812 we dwunastu ksieggach wierszem, Warszawa 1982.

Opozycja demokratyczna $w$ działaniach władz PRL [dyskusja z 3.06.2003 r. odbyta przez Łukasza Kamińskiego, Antoniego Dudka, Jerzego Eislera, Andrzeja Friszke, Henryka Głębockiego i Grzegorza Waligórę], „Pamięć i Sprawiedliwość", 2003, nr 2, s. 33-68. 
Rys historiograficzny dekady gierkowskiej...

Pużyński A., Rozwój społeczno-gospodarczy Polski w latach siedemdziesiątych, Warszawa 1978.

Rolicki J., Edward Gierek - przerwana dekada. Wywiad rzeka, Warszawa 1990.

Rolicki J., Edward Gierek. Replika - prawda do końca..., Warszawa 1990.

Rolicki J., Edward Gierek. Życie i narodziny legendy, Warszawa 2002.

Sasanka P., Czerwiec 1976: geneza, przebieg, konsekwencje, Warszawa 2006.

Sasanka P., Punkt zwrotny dekady Gierka, „Wiadomości Historyczne” 2004, nr 5, s. 3-19.

Sasanka P., Spałka P., Czerwiec 1976. Spory i refleksje po 25 latach, Warszawa 2003.

Sasanka P., Stępień S., Czerwiec 1976. Radom, Ursus, Płock, Warszawa 2006.

Skórzyński J., Siła bezsilnych. Historia Komitetu Obrony Robotników, Warszawa 2012.

Słabek H., Chłopi-robotnicy, robotnicy-chłopi, robotnicy-działkowicze (19451989), „Kwartalnik Historyczny” 2002, nr 2, s. 77-100.

Słabek H., Kościół katolicki w Polsce 1945-1989, „Dzieje Najnowsze” 2005, nr 2, s. 113-139.

Słabek H., O społecznej historii Polski 1945-1989, Warszawa 2009.

Szczęsna J., W kościele św. Marcina, „Zapis”, 1977, nr 4, s. 37-57.

Szlachcic F., Gorzki smak władzy, Warszawa 1990.

Tejchma J., Kulisy dymisji. Z dzienników ministra kultury 1974-1977, Kraków 1991.

Tejchma J., Pożegnanie $z$ władza, Warszawa 1996.

Waligóra G., ROPCiO, Warszawa 2006.

Wójcik P. (red.), Elity władzy w Polsce a struktura społeczna w latach 19561981, Warszawa 1994.

Z dziejów politycznych Polski 1944-1984, H. Dominiczak, R. Halaba, T. Walichnowski (red.), Warszawa 1984.

Zaremba M., Bigosowy socjalizm dekady Gierka, „Więź” 2003, nr 5, s. 106-119.

Zaremba M., Komunizm, legitymizacja, nacjonalizm. Nacjonalistyczna legitymizacja władzy komunistycznej w Polsce, Warszawa 2001.

Zaremba M., Od wojny domowej do solidarnościowej rewolucji, czyli społeczeństwo nieprzedstawione dekady lat siedemdziesiatych, „Res Publica Nowa” 2000, nr 8, s. 46-54.

Zieleniewski M., Przez lekko uchylona bramę Gierek, Jaroszewicz, Babiuch, Cyrankiewicz, Szlachcic i inni, Kościan 1989.

Żaryn J., Dzieje Kościoła katolickiego w Polsce (1944-1989), Warszawa 2003. 


\begin{abstract}
In article I amtrying to summarise polish historiography about Gierek's decade. Since the end of this period only 35 years have passed, but even now we can define some plots on that field. Historical literature upon that thing can be divided into four periods. In some of them we can find more or less critical discourses. The paper help us figure out which was dominant in current period. In that way we can recapitulate how was seen "the decade of accelarated development” in polish historiography, was it a „paradise”, or opposite.
\end{abstract}

Keywords: Edward Gierek, 1970s, PRL, historiography 